\title{
Exergy and the City: the Technology and Sociology of Power (Failure)
}

Hugh Byrd and Steve Matthewman

ABSTRACT Blackouts - the total loss of electrical power - serve as a reminder of how dependent the modern world and particularly urban areas have become on electricity and the appliances it powers. To understand them we consider the critical nature of electrical infrastructure. In order to provide general patterns from specific cases, a large number of blackouts have been analysed. Irrespective of cause, they display similar effects. These include measurable economic losses and less easily quantified social costs. We discuss financial damage, food safety, crime, transport and problems caused by diesel generators. This is more than just a record of past failures; blackouts are dress rehearsals for the future in which they will appear with greater frequency and severity. While energy cannot be destroyed, exergy - the available energy within a system - can be. Exergy is concerned with energy within an "environment;" in this case a city. The bottom line is simple: no matter how "smart" a city may be, it becomes "dumb" when the power goes out.

\section{KEYWORDS Blackouts; Network Failure; Critical Infrastructure; Electricity; Cities}

Correspondence Address: Hugh Byrd. The School of Architecture, Brayford Pool, The University of Lincoln, LN6 7TS, UK. Email: hbyrd@lincoln.ac.uk

\section{Introduction: Accidents and Network Failure}

The Economic and Social Research Council (2004) urged that the project for $21^{\text {st }}$ century social science should be to reckon with the accident: urban vulnerability, network failures and states of emergency. Our paper is a contribution towards this project. It focuses upon a particular network failure, the accidental loss of electrical power commonly referred to as blackouts or load-shedding. Our motivations for doing so are threefold: i) blackouts - including supra-national ones - are on the rise, ii) ‘blackout risk is generally underestimated’ (Bruch et al., 2011: 3, 25), and, iii) dedicated studies of infrastructural failure continue to be few and far between (Graham, 2010: 2). Our discussion follows Charles Perrow's (1984: 64) definition of accidents as unintended events that damage people, materials and systems. We have reviewed fifty different significant power-outage events that have occurred in twenty six countries mostly over the last decade. The unpredictable nature of blackouts and their often serious aftermath limit the collection of field data. Hence much of the information in this paper is collected from reputable media coverage of the events. This has been supplemented by emergent secondary literatures, academic (Luke, 2010; Nye, 2010) and technical (Bruch et al., 2011; UCTE, 2004).

While many blackouts are caused by accidents best described as systems failures we observed a number of network failures due to inadequate energy, whether it be depletion of resources such as oil and coal or the vagaries of the climate in the supply of renewable energy. The inadequate supply of resources offers a glimpse into likely future trends for cities in many countries. For those that rely heavily on fossil fuels to generate electricity, the peak production of resources such as oil and coal is already evident. By way of example, the UK Government’s incoming energy adviser stated in 2009 
that "[t]here is a worry that in 2016 there might not be enough electricity" (MacKay quoted in Harrabin, 2009). This point has been reinforced more recently by the British energy regulator Ofgem, which predicts a fall in spare electrical power production capacity to two per cent by 2015. This will significantly increase blackout risk (BBC, 2013). The World Bank (2010) called its analysis of energy in thirty countries in Eastern Europe and the former Soviet Union Lights Out? The issue of energy security still remains for those fortunate countries to have access to significant renewable energy supplies (Burnham and Groneworld, 2010). Rain, wind and sunshine are not always dependable and are becoming less predictable with climate change. Our survey revealed that blackouts in Kenya (Burnham and Groneworld, 2010), India (BBC, 2008b), Tanzania (BBC, 2006) and Venezuela (BBC, 2010) were caused by shortages of rain for hydro dams.

Understanding the nature of blackouts is more than just a record of past failures; blackouts are dress rehearsals for the future in which they will appear with greater frequency and severity and, as urban areas become more compact, with greater consequences. We predict increasing numbers of blackouts due to growing uncertainties in supply and growing certainties in demand. Supply will become increasingly precarious because of peak oil, political instability, industry liberalisation and privatisation, the precariousness of energy delivery systems, infrastructural neglect, global warming and the shift to renewable energy resources. Demand will become stronger because of population growth, rising levels of affluence and the consumer 'addictions' which accompany it. ${ }^{1}$ In the following section we consider the frailty of the electrical power system, we then consider the social consequences of power blackouts, before closing by considering two consumer 'addictions' that impact urban areas: current air-conditioning use and potential future electric vehicle (EV) use. Our final comments here relate to liberalisation and privatisation.

Deregulation and privatisation have been major global trends within the electrical power industry across the past two decades. There is broad consensus amongst energy specialists, national advisory bodies, the reinsurance industry and organisational sociologists that these trends have exacerbated blackout risk. Alliteratively, we can express their related concerns as: complexity, communication and competition. Liberalisation and privatisation has seen the separation of generation, transmission and distribution services. "Just by the sheer complexity, adding one thing to another, larger and larger disturbances are going to occur” (Schewe quoted in Glanz, 2003). The American Society of Civil Engineers (2009: 134) notes that there are over 3100 electric utilities in the United States. Here power is often sold by utilities over lines that are not their own (Amin and Schewe, 2007: 63), and such activities take place across ever-greater distances (Luke, 2010: 61). Delivery systems become more complex as distances and interconnectivity increase. Even neighbouring utilities are likely to be using different control protocols (Amin and Schewe, 2007: 63). This, then, is a problem of interoperability - the ease with which different technical and human

\footnotetext{
1‘Addiction' is not used here in a strict clinical sense but it is used to signal notions of physical and psychological dependence.
} 
systems are able to speak to each other. Communication failures (in liberalised and privatised systems) are directly implicated in two of the world's worst blackouts: the August 14, 2003 blackout which stretched from Ohio to Ontario and the September 28, 2003 blackout in Italy and neighbouring nations (Bruch et al. 2011: 26-7). In their combination these two events affected over 100 million people.

In a competitive environment reliability and profits may be at cross-purposes - single corporations can put their own interests ahead of the shared grid, and spare capacity is reduced in the name of cost saving (Little, 2010: 32-3). There are no real incentives to maintain, better or supplement transmission lines (Perrow, 2007: 246). The American Energy Innovation Council (2011: 5) notes generic problems with the private sector: they are poor at providing public goods like environmental protection, and they continually under-invest in research and development relative to potential social gains as it is difficult for particular firms to realise all of the financial benefits of such investments. Massoud Amin and Phillip Schewe (2007: 67) concur, they observe that research and development in the electrical utility sector is at an "all-time low.” The energy sector also brings more specific problems. Energy is not intrinsically valued; rather its worth comes from its provision of goods and services. Product differentiation is therefore not an innovation driver. Moreover it is a capitalintensive sector requiring significant up-front costs while enjoying relatively slow returns. This results in high levels of industry inertia. Finally, these markets are not perfectly competitive (American Innovation Council, 2011). "Deregulation and competitive pressures were introduced in order to increase efficiency and lower prices. Neither of these occurred," writes Perrow (2007: 246), "the mainstays of efficiency - maintenance and a professional workforce - have both declined, and after a long-term secular trend of lower prices, the cost of electrical power has risen since deregulation. Reliability has arguably declined.”

\section{Invisible Infrastructures: Critical Vulnerability and the Technological Unconscious}

Nigel Thrift (2005: 212-4) uses the term the 'technological unconscious' to refer to those invisible infrastructures that make everyday life possible while escaping everyday attention. He is not the only person to direct us to this overlooked domain. For Paul Edwards (2003: 185) these infrastructures are nothing less than "the invisible, unremarked basis of modernity itself.” Geoffrey Bowker and Susan Leigh Star (2000: 33) argue that infrastructural absence from the collective conscience is a function of use and size. The easier technologies are to use the less we actively reflect upon them, and the more pervasive they are the less we seem to notice them. The lesson seems to be that the better they work the less obvious they become. This is what makes modern technology so remarkable: it simply fails to register except for when it fails. Yet accidents are to be expected in complex hi-tech assemblages in both cities and the infrastructure that connects them, indeed, there is “an 'accidental normality' at the core of systematised complexity” (Luke, 2010: 67). This is because 
the potential exists for failures within the system to interact with each other in unanticipated and often incomprehensible ways. These will be particularly devastating in tightly coupled systems like the US and European energy grids, where processes are rapid, intimately linked and hard to stop. (The classic exposition of this position is to be found in Charles Perrow's (1984) book, although interestingly he did not see the electrical grid as being liable to normal accidents as it was tightly coupled but not complex. This is corrected by his later work which devotes an entire chapter to blackouts as normal accidents on the US power grid in the context of deregulation and privatisation (Perrow, 2007: 21147).)

Even when acknowledged, Paul Edwards (2003: 190) writes, our routine explanations for accidents fail us too. Electrical power blackouts are reported as human errors or as technological shortcomings. These tend to be the standard stories of the energy industries. The problem is either reduced to the level of individuals or to nuts and bolts. This binary of blame - people or hardware obscures the systemic nature of accidents and network failures, which are the outcome of relations between people, technical systems, resources, institutions, regulatory frameworks, environmental conditions and social expectations (we found various causes of blackouts which we list in the following section). To reiterate, "power blackouts are not caused by a single event. There is no outage known where a faultless grid collapsed completely due to a single cause” (Bruch et al., 2011: 9).

In the privileged west we may assume a continuous and stable supply of electricity. This assumption will be increasingly challenged. Electrical power generation and distribution is less reliable than we might surmise. Power does not consistently flow along the same predetermined path. When a supplier sends power to another it increases the power supply, while the receiver either reduces production or has increased demand. Power goes from 'source' to 'sink' along connecting paths. Shifts in generation and transmission anywhere within the system alter loads on generators and transmission lines at all other points, the consequences of which may not be fully anticipated or managed (Lerner, 2003: 8).

The normal way to guard against system failure is to ensure that power flows remain below the transmission line's capacity. When the capacity limit is transgressed the lines overheat. This may cause them to sag, generate unstable power supply or even fail. Longer power lines result in greater losses. Further vulnerabilities arise because AC power grids need the frequency and phase of all power generation to synchronise within tightly defined limits. Circuit breakers are used to remove generators from the system if their frequency fluctuates too greatly. However, when "certain parts of the grid are carrying electricity at near capacity, a small shift of power flows can trip circuit breakers, which sends larger flows onto neighbouring lines to start a chain reaction failure” (Lerner, 2003: 10).

Electrical power is not merely infrastructure. It meets the International Risk Governance Council's (IRGC) definition of critical infrastructure. Critical infrastructures are large-scale humanbuilt systems that supply continual services central to society's functioning. They are both the subject and source of numerous threats. These systems typically have no single owner, manager or controller. 
Interests and operating procedures therefore have the potential to diverge and conflict (Kröger, 2005). This is all too apparent with electrical power, where the physics of the system can be further complicated by its administration. For example the North American power grid is a single machine arguably the world's largest (Lerner, 2003: 8). But this unified physical system is politically fragmented. It crosses a variety of borders, competing corporate spaces and regulatory zones.

The vulnerability of the electricity system is ably demonstrated by a blackout which took place on September 28, 2003. This rapidly escalated into a grid collapse. It was the nation's worst blackout in half a century. The event began when a falling tree broke an electrical power line in Switzerland's Lukmanier Pass. The nearby San Bernadino line subsequently overloaded. Twenty four minutes after the first tree flashover, a second tree came down in the San Bernadino Pass. Two important lines failing were too much for the system to bear. Moments later the overloads tripped the other interconnectors towards Italy, separating the country from Europe's electricity network (UCTE, 2004: 4-5). The low voltage level in the north of the country caused several Italian power plants to trip. All of Italy, which is to say some 55 million individuals, was left without power. It says something about the fragility, complexity and interconnectivity of the modern world when a nation is brought to a halt by two trees falling outside its territory.

The IRGC measures criticality by space, size and time: the geographical spread of failure, the severity of its effect and the speed with which it is felt. Failure in the electric power network is potentially international in scale, it can profoundly affect those within the afflicted area, and it can do so immediately (Kröger, 2007: 10). Network failures of this type are about as critical as it can get. Consider the manifold ways in which we routinely use electricity for lighting, cooling and heating, cooking and refrigeration, banking, communicating, and commuting. Additionally, disruptions to critical infrastructures are likely to have rippling effects as they are dynamic and interdependent arrangements. Electricity powers, connects to and synchronises with other systems. Worryingly, " $[t]$ he issue of interdependent and cascading effects among infrastructures has received almost no attention” (Little, 2010: 33). Blackouts affect pumps, refrigeration, traffic lights, trains, and cell phone towers. This has serious consequences for water, waste, food, transportation and communication systems. Indeed, modern social life is impossible to imagine without it. Our relationship to electricity and the appliances it powers is one of absolute dependence. As Mark Abley put it: "we are all now hostages to electricity" (quoted in Leslie, 1999). Let us examine some of the patterns that emerge when the power goes out.

\section{Patterns of Network Failure: The Social Effects of Blackouts}

This paper pulls together the threads and themes of blackouts. Our survey shows that they have numerous causes, including: technical failure (BBC, 1998b), extreme weather events (Aljazeera, 2009; BBC, 2003b), geomagnetic storms (National Research Council, 2008: 3-4), political spite 
(BBC, 2011), sabotage (The Advocate, 2014), deceiving the enemy during war (New Zealand Herald, 2001), all-out war (Graham , 2010: 24), cyber-attack (Espiner, 2008), vandalism (EATON, 2012: 6), inadequate generation capacity (BBC, 2004a; Iqbal, 2010; McGreal, 2008a), financial problems (BBC, 2001), corruption (Cist, 2008; Dummet, 2009; Gatehouse, 2010), increases in air-conditioning use (Energy News, 2014), damage by animals (EATON, 2012: 6), and a lack of resources to generate electricity. Resource lack applies to both fossil fuels (BBC, 2004b; BBC, 2008b) and renewable energy sources (BBC, 2010; Daily Nation, 2009; Haviland, 2009).

When these accidental events happen, the electrical supply industries are faced with establishing future mitigation systems. Research and risk analysis is carried out with the aim of producing a resilient supply in the future. For example, the electricity supply industry produced a book on improving supply security following the Italian power outage in 2003 (IEA, 2005). However, little research is carried out on the social impact of power outages (for notable exceptions see Yuill, 2004 and Nye, 2010). Irrespective of cause, patterns emerge whenever blackouts result. These include measurable economic losses and social costs that are far harder to quantify. Here we focus on economic damage, food safety, crime, transport and the problems caused by the diesel generator.

For several blackout events that have occurred internationally, the direct monetary cost has been calculated. This is generally measured using a simple economic model such as loss of sales or production. The examples here show that losses vary considerably from minor inconveniences of ATM machine failure, as in the UK in 2009 when a major bank lost its power supply serving as a reminder of how dependent and vulnerable the banking industry is to an interrupted electricity supply (Alexander, 2009), all the way to major economic failures costing hundreds of millions of dollars. Power outages and quality disturbances are estimated to currently cause economic losses of between USD\$25 and USD\$180 billion per annum in America (ASCE, 2009: 134), with insurance industry experts suggesting that indirect costs are typically in the order of up to five times higher than direct ones (Bruch et al., 2011: 15). During Easter 2010 Venezuela’s president extended the holiday period in order to reduce the country's electricity demand. Rolling blackouts were imposed on areas of the country and the business community warned the president of a loss of production and food supply shortages. It was also reported that tax return deadlines, due on April 1, were unlikely to be met. Turning lights out to keep others on can be more politically expedient than maintaining production (Guardian, 2010). 25 January 2008, the three largest gold mines and two biggest Platinum mines in South Africa were forced to shut down due to a blackout. Within minutes, the world price of these commodities rose by 5 per cent (McGreal, 2008b). Power cuts in Iran in September 2008 added to the economy's woes: “Without electricity, the economy continues to self-destruct. In the scorching heat, offices cannot operate without air-conditioners and the little manufacturing done in Iran is threatened with even more disasters. Making deals with China necessitated the opening up of the Iranian market to cheap Chinese goods so at this rate the little of it done at home will be destroyed” (Cist, 2008). Beijing, China in July 2004 rolling blackouts occurred as energy demand soared. To compensate, 
factories operated only at night to save energy on air-conditioning use and the state press urged people to stop wearing suits as a means of keeping cool. Driven by an inadequate supply of resources, state governments introduced rationing of electricity with the logic of turning lights off in one place in order to keep them on in another (BBC, 2004a). On 15 August 2003 parts of Canada and the US were hit by a blackout. Trading on the stock exchange was described as "light," people struggled to get to work and ATM machines stopped functioning. Car manufacturing was hit hard with 12 General Motors and 24 Ford plants closing. Five US and two Canadian airports were closed resulting in about 500 flight cancellations and an estimated "tens of millions of dollars" in losses (BBC, 2003a). Italy was crippled by a grid collapse the following month. The 18 hour blackout exposed the country to almost every aspect of dependency that comes with an addiction. Only a few hours into the blackout it was estimated that the loss of food sales amounted to $€ 50$ million with the loss of frozen food adding a further $€ 70$ million Euros (BBC, 2003b). In Auckland, New Zealand, the 5 week long blackout that hit the central business district and surrounding areas was estimated to cost NZD\$120 million to restore the power supply, NZD\$ 110 million to protect the new cable installation and a further NZD\$70 million for compensation claims (BBC, 1998a). A simple failure of cables burning out caused the evacuation of the CBD and shut down the City economy for weeks. In Chile blackouts in some of the most populated areas, including Santiago, left offices, shops, and traffic lights without power for a couple of hours at a time over a period of a week in 1998 (BBC, 1998d).

Blackouts severely impact upon foodstuffs. The need to keep food fresh through the use of fridges and freezers is a priority. The inability to safely store food has a number of consequences. Economic loss is perhaps the most immediate and obvious. For example, in May 2008 traders in Zanzibar soon found their stock perishing. Meat went bad due to blackouts that lasted several days. Some shopkeepers looked to claw profits back by buying fresh meat at reduced prices, only to find that no market existed for it. Customers were every bit as reliant on electrical power. The blackout deprived them of the means of cooking (BBC, 2008a). Blackouts were so frequent in Kenya during 2010 that Nairobi's restaurants planned their menus to accommodate them. With each blackout staff scrambled to get generators running to avoid food spoilage, but cooks could never meet demand due to the lack of stoves. Restaurant owners noted the frustration of serving a restricted number of offerings to their customers and the fear of potentially poisoning them (Burnham and Groneworld, 2010). In 2010 authorities imposed electricity rationing to meet energy efficiency targets in Hebei Province China. Tens of thousands of households were left without electricity for 22 hours out of 3 days with the consequent loss of refrigeration. Milk curdled and vegetables rotted as the domestic penalty for industries that exceeded targets for energy consumption (Watts, 2010). A more tragic consequence of a lack of refrigeration was felt in Pakistan in June 2010. Load-shedding during a heat wave resulted in 12 hours a day without electricity. Hundreds died of food poisoning as the poor ate bad food from their freezers (Iqbal, 2010). 
When the lights go out, crime rates increase. Without electricity security systems fail. Blackouts provide opportunities for fraud, theft and exploitation (BBC, 2009a, b). In South Africa in 2008 an increase in robbery occurred during times of blackouts including premeditated and violent robbery from cars returning home and being delayed in the street while electric gates had to be opened manually (McGreal, 2008a). In Zanzibar, following four weeks of an electricity blackout it was announced that power had at last been restored. But not for many, as the opportunity for making money out of the scrap metal value of electricity cables was too tempting while the cables were not live (Boswell, 2008). In 2006 in Tanzania the rains failed and the hydro dams ran almost dry. The Energy Minister realised the importance of electricity: "It is important to have light at night to curb crime” (BBC, 2006). Auckland, New Zealand, suffered a blackout for five weeks (BBC, 1998a). The police adopted saturation policing, doubling patrols and using private security guards to prevent looting. However, it was the only place in the sample where crime reportedly reduced. As the city centre closed down after weeks of a blackout, visitors left and the empty streets offered little opportunity for petty criminals. The BBC's headline read: “Kiwi Blackout Drives Criminals off the Streets.” More typically, extended periods without electricity or intermittent periods of rolling blackouts caused by load shedding, lead to unrest. In Pakistan it was estimated that 53 per cent of the population went without power for 8 hours of the day in 2009. The power cuts tend to occur during the hot summers. The high temperatures and hikes in energy prices were a recipe for unrest. "In Karachi and throughout the Punjab ... angry mobs went on a rampage and assailed power companies in frustration at the long daily power cuts that have brought modern life to a standstill” (Iqbal, 2010).

One of the most immediate and prevalent problems with blackouts is the loss of traffic lights and consequent dangers. Traffic jams and accidents were a recurring theme in the enforced blackouts in China in 2010 (Watts, 2011), the 2009 Brazilian blackout (Aljazeera, 2009), the 2003 Italian blackout (BBC, 2003b), and the 2001 California blackout crisis (BBC, 2001a). Similar issues with the South African blackouts of 2008 prompted the Government to consider replacing the electrical supply to traffic lights with solar powered electricity (McGreal, 2008b). Public transport is another victim with the loss of subway trains below ground and rail systems above. Thousands of people were stranded in Brazilian cities after the world's largest power outage occurred in 2009 (Aljazeera, 2009). The power cut shut down the subway system in São Paolo’s financial centre trapping thousands inside.

In September 2003, underground trains in Italy stopped in the blackout trapping passengers inside for hours. 110 trains were halted, some for 12 hours with an estimated 30000 passengers affected (BBC, 2003b). One month earlier, in New York, the subway stopped, trapping commuters inside. The Mayor urged non-essential workers not to travel. Electric buses and underground railways also came to a halt in the Iranian blackout of 2001 (BBC, 2001b). Air travel is also sensitive to these failures due to a loss of communication systems and lack of runway lighting. Parking also becomes 
problematic. Security gates cease to operate causing problems to those stuck inside, and outside, secure parking areas.

Given the problems detailed above, diesel-fuelled generators may appear as a lifeline to householders, hospitals and businesses. They can offset the deleterious effects of accidental power outages. However, complaints about noise and air pollution caused by this equipment are a common theme in blackout events. Furthermore, the cost of generators and the fuel to run them are prohibitive to all but the most privileged. Generators, then, also operate as symbols of wealth, a divisive tool that emphasises the rift between rich and poor. In June 2010, a combination of war, corruption and incompetency left Baghdad with electricity for only 2 hours per day. Residents complained of "the din of a thousand diesel engines” (Gatehouse, 2010). Small business owners suggested that as much as half of their income goes on fuel and servicing costs for generators (Gatehouse, 2010). In the Gansu province of China in the second half of 2010, local government enforced rolling blackouts and factory shutdowns in order to reach its energy efficiency targets. As a consequence, the use of diesel generators surged so that factories and homes could produce their own electricity. Competition for diesel fuel ensued between its traditional use for transport and the new use of private electricity generation, causing cues for diesel at filling stations (Watts, 2011). In Pakistan in June 2010 the combination of record-breaking temperatures $\left(53^{\circ} \mathrm{C}\right)$ and 12 hours a day without electricity made life without fans, fridges or air-conditioning more than just an inconvenience, it could make all the difference in the world. For those rich enough, a generator is an essential piece of equipment. "The wealthy will switch on their generators to keep a running supply of power every time the electricity trips,” wrote Nosheen Iqbal (2010), but “the poor are simply left to swelter and suffer.” After years of war, corruption and general neglect, Nepal's electricity supply was rationed in 2009. Reporters wrote of "severe and unprecedented” power cuts, with around 16 hours a day of blackout (Haviland, 2009). With this level of electricity interruption schools, businesses, private hospitals and households cease to function properly. To be able to maintain some level normality, those who could afford it purchased a generator: "the rich are buying generators and the poor are having to re-plan the patterns of their lives” (Haviland, 2009). Blackouts in Zanzibar (BBC, 2008c) and Tanzania (BBC, 2006) had a similar impact with the noise of generators being heard throughout urban centres. Demand for generators in Zanzibar was so great that that they sold out. Buying them was one thing, running them another. Small businesses purchased generators but the cost of fuel resulted in unsustainable trading. One cafe owner estimated the running costs to be USD $\$ 100$ a day. Residents likened this daily cost to “the equivalent to half a month's electricity bill” (BBC, 2008c).

\section{‘Addictions’ Current and Future: Air-Conditioning and Electric Vehicles}

So far we have cast light on an ordinarily invisible infrastructure, noted its critical nature and detailed some of the consequences of its failure. Yet our dependency upon electricity grows ever- 
greater. Electrical demand will continue to increase (IEA, 2010: 77), fuelled in part by consumer 'addictions.' We consider current demand for air-conditioning and predicted demand for EVs.

Calling our relationship to air-conditioning an addiction might seem an overstatement, yet a number of scholars looking in a range of geographical locations have noted our powerful attachment to it, sometimes using this very term (Cândido et al., 2009; Chun et al,. 2008; de Dear and Auliciems, 1988; Prins, 1992). Once acclimatised to it we are loathe to give it up. "By building a world around air-conditioning,” writes Stanley Cox (2010: 33), “we have made it an essential technology.”

Air-conditioners have affinities with diesel generators. Both offer solutions to private problems, while simultaneously creating much larger collective ones. Generators generate more than electrical power, they also produce community envy, air and noise pollution. Air-conditioners cool and dehumidify domestic and commercial space, but in doing so they heat the environment and they are linked to ozone depletion. Short-term private gain may come at the expense of long-term public pain. Without a trace of irony PR Web (2008) could open its press release on predicted air-conditioner sales thus: "Depletion of the ozone layer, El Nino effect, global warming, and rising population are all hot factors that are driving ahead the need for a cool world.” No causal link was inferred. It suggested that such devices are no longer luxuries but necessities, and necessities create opportunities.

Currently, none can compete with the US, which Cox (2010: 32) describes as "the undisputed champion” of air-conditioning. The statistics speak for themselves: air-conditioning accounts for 20 per cent of the country's domestic electricity consumption, and 13 per cent of the commercial sector's, figures which equal the entire African continent's overall electrical demand. The government believes that cooling consumption will grow by a further 22 per cent over the next two decades in the commercial sector. This will add an additional burden to utility companies that are also being pressured to reduce greenhouse gas emissions. Electricity generation by American utilities currently produces 2.5 billion metric tons of carbon dioxide and 11 million tons of sulphur dioxide per year. In 2007 commercial and residential air-conditioning consumed 484 billion kilowatt hours of electricity, a number which the author notes is not much lower than total US energy consumption in the mid-fifties. This could not be supplied by renewable sources, even if the entire nation's was utilised (Cox, 2010: $37,43)$.

But the US is now regarded as a saturated market, the real growth will occur elsewhere. The PR Web cited a Global Industry Analysts study which predicted sales of 85.4 million units in 2012. Asia-Pacific was both the fastest growing and the most significant market. Air-conditioners already constitute 20 per cent of overall Chinese electricity consumption (Teske, 2010: 188), where household ownership of air-conditioners has tripled in the decade since 1997 (Cox, 2010: 44), and the claim has been made that 40 per cent of Mumbai's electricity consumption goes on air-conditioning (Planet Green, 2010). We once thought nationally, now we now have to think globally.

In 2009 Morna Isaac and Detlef van Vuuren of the Netherlands Environmental Assessment Agency published the first planetary study of residential demand for domestic heating and cooling set 
within the context of global warming. Their work paints an alarming picture. According to their predictions world demand for heating rises until 2030 after which time it stabilises. By contrast, demand for air-conditioning is projected to rise rapidly to 2100. This is mostly a function of rising prosperity. The shift from heating to cooling spells bad news for the climate, for in many countries (like the US) cooling is more carbon intensive than heating. Moreover, the demographic trends show that most people will live in the tropics, where cooling demand will increase along with its cost. They estimate that the energy demand for cooling in 2100 will be 40 times greater than it was in 2000 (Isaac and van Vuuren, 2009: 513). An earlier, more limited, study suggested between 18-25 per cent less cold weather per annum four decades hence and 17-23 per cent more hot weather. Population increases (which, as noted, will be greater in hotter regions) and global warming would make for a 6572 per cent increase in cooling demand (Stein and Lemke cited in Cox, 2010: 31-2).

Gwyn Prins (1992: 251) described America’s physical attachment to air-conditioning as that nation's “most pervasive and least noticed [current] epidemic.” An epidemic, we should add, that is spreading around the globe. We want to suggest that EVs are shaping up to be a future 'addiction.' A 2010 consumer survey in major markets by Ernst \& Young showed that serious demand for EVs already exists. A quarter of those questioned were interested in purchasing one (Shankar, 2010). Ernst \& Young's Global Automotive Leader predicted that demand would exceed supply for the 2010 and 2011 production runs. Richard Gilbert and Anthony Perl’s (2008) had already forecast growing demand for EVs relative to internal combustion engines (ICEs) as they are quieter, more energy efficient and less likely to require maintenance.

Vehicle producers have become increasingly interested in EVs. The International Energy Agency (2010: 5) identified a single political 'megadriver' for this: G-20 and APEC pledges to eventually eliminate inefficient subsidies for fossil fuels, the total cost of which they estimated to be USD\$312 billion in 2009 alone. The World Bank’s (2011: 1) view is broader. It highlights four supply and demand 'megatrends' driving vehicle electrification: the aforementioned climate change policies aimed at reducing (vehicular) carbon dioxide emissions, concerns about the cost and security of oil supply, increasing congestion and attendant air pollution, and impressive technological breakthroughs regarding batteries. Combined, they make mass markets for such vehicles possible. Battery electric vehicles (BEVs) were less attractive to most consumers than ICEs because they travelled shorter distances, had less power, and took longer to refuel. All of these problems relate to the battery's lower energy density. For example a standard nickel metal hydride battery has 180 times less energy density than petrol. But new battery prototypes are showing great promise. They have long range and are more fuel efficient than petrol (Gilbert and Perl, 2008: 149).

The International Energy Agency's EV forecasts go to 2035. They offer a range of scenarios. Their best case one for EV sales is the 450 Scenario. This is named after the limitation of the longterm concentration of atmospheric greenhouse gases to 450 parts per million of $\mathrm{CO} 2$ equivalent to ensure global temperature rises of no more than 2 degrees centigrade above pre-industrial levels. 
Assuming this strong policy orientation towards countering the effects of global warming, there would be sales of almost 65 million EVs and plug-in hybrid electric vehicles (HEVs) by 2035 (IEA, 2010: 433). The World Bank’s EV forecasts only go out to 2020. In their estimation plug-in HEVs and EVs could total 10 per cent of all new vehicle sales by then (World Bank, 2011: 7). This would create an estimated EV value chain of over USD $\$ 250$ billion. The figure factors in the cost of energy generation and distribution, fuelling and infrastructure, batteries and other components, and the EV vehicles themselves, but the calculation does not include advertising, branding and services.

Such demand would add USD\$20 billion in incremental electricity sales (World Bank, 2011: 28). Gilbert and Perl (2008: 161) calculate that, ceteris paribus, “converting the personal vehicle fleet to electric drives in a higher-income jurisdiction would increase the amount of electricity that has to be generated by 15-40 per cent.” While the required generating capacity could be significantly lower than this figure if batteries are charged during off-peak periods, it none the less remains true that increased demand for EVs necessarily increases demand for electrical power. Cox (2010: 43) relates the discussion back to where it began in this section: "If all household vehicles were to be replaced with highly efficient electric models, with no reduction in numbers, the new cars would still consume on the order of twice as much electricity as residential and commercial air-conditioning combined.”

The load shedding that occurred in Nepal in 2009 offered a glimpse of the vulnerability of one particular mode of electrically-powered transport that is likely to replace the internal combustion engine in many countries in the future. The nation obtains much of its energy from hydroelectricity and has a significant number of electric vehicles. Kathmandu has about 700 battery-operated tempos or rickshaws, each of which carries about 10 passengers. But with the power cuts, there was insufficient time to recharge their batteries daily. By the time the families of the rickshaw operators were factored in, the chairperson of the Electric Vehicles Association of Nepal estimated that at least 10000 people had been adversely affected, and that figure excluded passengers (Haviland, 2009).

\section{Conclusions}

Grid supplies of electricity have democratised energy distribution in many countries across the world. The immediate, cheap and reliable supply of electricity has allowed economies to develop at an unprecedented rate in history. This supply is generally taken for granted in western societies which have developed an 'addiction' to the tools and appliances that are driven by this form of energy. We have become dependent on air-conditioning, computers, lights, fridges and freezers that are, in turn, dependent on an uninterrupted supply of electricity. Such is our dependency that our comfort, security, communication systems, transport, health, food supply, businesses and social equity systems collapse when electricity supplies are interrupted. The continuing sophistication and prevalence of electrical appliances only serves to increase our dependence. 
Yet it will become ever more difficult to meet demand for electricity. Increasing numbers of people are living longer and enjoying rising living standards. This increases demand for electrical appliances (IEA, 2010:89). In 2008 the world's population was 6.7 billion. This is predicted to rise to 8.5 billion by 2035. Across the same time period it is estimated that demand for electricity will grow by 80 per cent. This will require an additional 5900 gigawatts of additional capacity (IEA, 2010: 77). Who will access supply is an important question. The World Bank, while agreeing that demand will grow, suggests that rising global primary energy costs, particularly for oil, will mean that a smaller proportion of the world's population will have access to electricity in 2030 than currently, raising serious questions about social justice, energy poverty and global security (Mehrota, 2011). Whether or not the necessary supply can be provided is also a fundamental consideration.

Even in the privileged west energy systems have suffered neglect. Infrastructural investment in both the US and Europe has been poor. New transmission facilities, though sorely needed, have not been high on the agenda. In consequence power grids are operating at close to capacity. This stops planned outages for routine maintenance and increases the risk of cascading blackouts. In a policy brief the International Risk Governance Council stated that the western electricity networks need "urgent action to reduce the potential effect of ... failure” (Kröger, 2007). Similarly, the American Society of Civil Engineers' (2009: 134) Report Card for America's Infrastructure noted several alarming facts: demand for electricity has increased 25 per cent since 1990, while construction of transmission facilities generally fell across three decades (see also Chu, 2009). It estimated that as much as USD \$1.5 trillion will need to be invested in electric utilities by 2030 to meet demand. A study by Greenpeace International and the European Renewable Energy Council showed that a great number of power plants in the US, Europe and Japan are nearing the end of their days. Over half are two decades old or more. The same holds for the majority of the planet's nuclear reactors, many of which are now being pushed to double their intended life expectancy (Teske, 2010: 36, 33). Greenpeace have suggested developing a European supergrid that relies heavily on renewable sources. They cost their proposal at €209 billion per annum until 2050 (Teske, 2010: 46). While this would offset some of the risk of blackouts it assumes a political will that is yet to exist and technologies that await perfection.

Technological fixes are routinely offered as the solution to a myriad of modern problems, power generation systems included. David Crane (2013), President and Chief Executive Officer of NRG Energy, writes: "It is not for lack of effort or money, but rather because the American power industry deploys technology designed in the 1800s to manage a system of wires and wooden poles that is ill-suited to the weather challenges of the $21^{\text {st }}$ century" (see also National Science and Technology Council, 2011: v). Doubtless a technological upgrade could help offset some of the anticipated threats which will come from anthropogenic climate change (as could more effort and more money), but the size, complexity and vulnerability of electrical grid systems means that they are always at risk. As such, they pose "ever-present structural threats to cities” (Luke, 2010: 55). 
The rolling out of 'smart grids' may be seen as the cure to the problems of blackouts. However, it is not as straightforward as it may first appear. In many instances the term 'smart' is an empty signifier. For example, the term 'smart meter' has been significantly abused (Byrd \& Matthewman, 2013) for marketing purposes and simply adding the term 'smart' does not necessarily imply that a meter, or a grid, is any less prone to problems. Also, the 'smart' technology adopted by these grids has introduced another way in which the grid can fail. For example, the blackouts in Brazil (BBC, 2009a) were assumed to be caused by a hacker who broke into the system. A further claimed feature of 'smart' grids are multiple routes. However, the old grids also featured multiple routes. Therefore, although improved features such as fault detection and self-healing will improve reliability, there are no guarantees that 'smart' grids will not fail.

Further, Bryan Wynne’s (1988) work shows us that even the experts might be at a loss to determine the consequences of any technologically-mediated activity (and when it comes to power grids no single individual or group has complete oversight). Wynne argues that experts work under greater ambiguity than is ordinarily supposed, particularly when they are involved with diffuse multisited operations. He identifies three salient elements under such conditions: institutional, contextual and systemic. First, as the work of organizational sociologists has demonstrated, organizations develop working routines and rules that are frequently at odds with official organizational norms. Second, technologies work in concrete and complex circumstances, including ones for which they were never originally designed (privatisation of formerly public power networks serves as a good example of this). Slippage can occur between various contexts of use as technologies are adapted for local conditions. Third, slippage is exacerbated in the case of large-scale systems where contextualization may only be partial, for example, parts are absorbed (or not) into the local regulatory structures and because of this the overall operating system is fragmented. When we have cross-cutting rationalities, such as will be brought on in a deregulated environment marked by competition between power providers, we have the potential for yet further problems. Wynne's (1988: 149) conclusion is that we should see "technology as a form of large-scale 'real-time' experiment" which enmeshes us all. Put another way, it is an accident waiting to happen.

Power supply is not simply under threat because of rapidly growing demand and the vulnerability of human systems, blackouts occur because of resource constraint: fossil fuel depletion and the transient nature of renewable energy sources. Peak oil and climate change are also causing an increase in the demand for electricity. The global preparations towards the widespread use of electric vehicles combined with the rapid spread of air-conditioning will create an even greater dependence on forms of energy with undependable supplies. As a consequence blackouts will become more frequent. This means that serious questions will have to be asked at both the individual and collective level concerning what we want and what we need, balancing what is good for us with what is good for others and ultimately what is good for the environment. 


\section{Acknowledgements}

The authors would like to thank the editor and the anonymous referees for their constructive and insightful comments.

\section{Note on contributors}

Hugh Byrd is Professor of Architecture at the University of Lincoln, UK.

Steve Matthewman is an Associate Professor in the Department of Sociology at the University of Auckland, New Zealand.

\section{Bibliography}

The Advocate, "Current Power Blackouts to Continue Nationwide," January 24 (2014) < http://www.theadvocatengr.com/index.php/component/k2/item/2741-current-power-blackoutto-continue-nationwide> Accessed 24 February, 2014.

R. Alexander, "Power Failure Hits HBOs Customers,” BBC News, November 14 (2009) $<$ http://news.bbc.co.uk/2/hi/uk_news/8360313.stm>

Aljazeera "Power Cut Hits Millions in Brazil," November 11 (2009) $<$ http://english.aljazeera.net/news/americas/2009/11/2009111132727141870.html>

American Energy Innovation Council, Catalyzing American Ingenuity: The Role of Government in Energy Innovation (Washington, DC: Bipartisan Policy Center, 2011) $<$ http://americanenergyinnovation.org/catalyzing-ingenuity-2011/> Accessed February 24, 2014.

American Society of Civil Engineers Report Card of America's Infrastructure (2009) $<$ http://www.asce.org/reportcard $>$

M. Amin and P.F. Schewe, "Preventing Blackouts,” Scientific American (May 2007).

BBC News "Ofgem Warns danger of Power Shortages has Increased,” June 27 (2013) $<$ http://www.bbc.co.uk/news/business-23081695> Accessed February 24.

BBC News “Power Cuts Loom for Venezuelans as Dam Runs Dry,” January 12 (2010) $<$ http://news.bbc.co.uk/2/hi/americas/8455592.stm>

BBC News “Brazil Blackout: Readers’ Accounts,” November 11 (2009a) $<$ http://news.bbc.co.uk/2/hi/americas/8354630.stm>

BBC News “Major Power Failures Hit Brazil,” November 11 (2009b) $<$ http://news.bbc.co.uk/2/hi/americas/8353878.stm>

BBC News "Melting in Zanzibar's Blackout," May 30 (2008a) $<$ http://news.bbc.co.uk/2/hi/africa/7427957.stm>

BBC News “Power Crisis Hits Indian States,” July 25 (2008b) $<$ http://news.bbc.co.uk/2/hi/south_asia/7524925.stm>

BBC News “Week-long Blackout Hurts Zanzibar,” May 28 (2008c) $<$ http://news.bbc.co.uk/2/hi/africa/7423444.stm>

BBC News “Tanzania Cuts Power after Drought,” February 2 (2006) $<$ http://news.bbc.co.uk/2/hi/africa/4673130.stm>

BBC News “Beijing “Brown-out” to Save Power,” July 22 (2004a) <http://news.bbc.co.uk/2/hi/asiapacific/3916789.stm>

BBC News “China’s Energy Supply Dwindling,” May 20 (2004b) <http://news.bbc.co.uk/2/hi/business/3732369.stm> 
BBC News “Firms Struggle to Resume Business,” August 16 (2003a)

$<$ http://news.bbc.co.uk/2/hi/business/3152871.stm>

BBC News “Huge Blackout Cripples Italy,” September 28 (2003b) $<$ http://news.bbc.co.uk/2/hi/3146136.stm>

BBC News "Italy Slowly Comes Back to Life," September 28 (2003c) $<$ http://news.bbc.co.uk/2/hi/europe/3146618.stm>

BBC News “Indian State Curbs Electricity to Industry,” May 30 (2002) $<$ http://news.bbc.co.uk/2/hi/business/2016611.stm>

BBC News “California Declares State of Emergency,” January 18 (2001a) $<$ http://news.bbc.co.uk/2/hi/business/1121453.stm>

BBC News "Power Blackout Hits Iran,” May 20 (2001b) <http://news.bbc.co.uk/2/hi/middle_east/1341027.stm>

BBC News “Normal Power Supply Still over a Week Away,” February 26 (1998a) $<$ http://news.bbc.co.uk/2/hi/asia-pacific/59641.stm>

BBC News “Auckland faces at Least 6 Weeks without Power," March 4 (1998b) $<$ http://news.bbc.co.uk/2/hi/asia-pacific/61828.stm>

BBC News “Kiwi Blackout Drives Criminals off Streets,” March 7 (1998c) $<$ http://news.bbc.co.uk/2/hi/asia-pacific/62952.stm>

BBC News “World: Americas Electricity Cuts Hit Chile,” November 19 (1998d) $<$ http://news.bbc.co.uk/2/hi/americas/217122.stm>

F. Boswell, “Zanzibar Celebrates Power Return,” BBC News, June 18 (2008) $<$ http://news.bbc.co.uk/2/hi/africa/7461995.stm>

G.C. Bowker and S.L. Star, Sorting Things Out: Classification and its Consequences, (Cambridge, MA: The MIT Press, 2000).

M. Bruch, V. Münch, M. Aichinger, M. Kuhn, M. Weymann, and G. Schmid, Power Blackout Risks: Risk Management Options, Emerging Risk Initiative Position Paper (Munich: CRO Forum, 2011).

M. Burnham, and N. Groneworld, "Water: Droughts Turn out the Lights in Hydro-dependent Region," Greenwire, May 10 (2010) $<$ http://www.eenews.net/public/Greenwire/2010/05/10/1>

H. Byrd, and S. Matthewman, 'Renewable energy in New Zealand: the reluctance for resilience'. In: Renewable Energy Governance. Springer. 2013

C. Cândido, R. de Dear, and R. Lamberts, "Cooling Exposure in Hot Humid Climates: Are Occupants 'Addicted'?” Architectural Science Review, 5 (2009) 59-64.

S. Chu, Investing in Our Energy Future, September 21 (Washington, DC: US Department of Energy, 2009) <http://energy.gov/downloads/investing-our-energy-future> Accessed February 24.

C. Chun, A. Kwok, T. Mitamura, N. Miwa, and A. Tamura, "Thermal Diary: Connecting Temperature History to Indoor Comfort,” Building and Environment, 43 (2008) 877-85.

M. Cist, “Iran’s Lights are Going Out,” The Guardian, September 2 (2008) <http://www.guardian.co.uk/commentisfree/2008/sep/02/iran.energy>

S. Cox, Losing Our Cool: Uncomfortable Truths About Our Air-Conditioned World (and Finding New Ways to Get Through the Summer) (New York: The New Press, 2010).

D. Crane "The $10^{\text {th }}$ Anniversary of the Northeast Blackout: Are We Any Better off Today?" Triple Pundit, August 12 (2013) <http://www.triplepundit.com/2013/08/10th-anniversary-northeastblackout-better-today/> Accessed February 21.

The Daily Nation “Power Outage Plunges Kenya into Darkness,” November 1 (2009) <http://www.nation.co.ke/News/-/1056/680492/-/uokf5x/-/index.html>

R. de Dear and A. Auliciems, "Air-conditioning in Australia - II - User Attitudes," Architectural Science Review, 31 (1988) 19-27.

K. Donald, "Brazil Power Cut Leaves Millions in Darkness," Sky News, November 11 (2009) $<$ http://news.sky.com/skynews/Home/World-News/Brazil-Power-Cut-Millions-WithoutPower-In-Sao-Paulo-And-Rio-De-Janeiro-After-ElectricalOutage/Article/200911215451224?lpos=World_News_First_Home_Article_Teaser_Region_ 1\&lid=ARTICLE_15451224_Brazil_Power_Cut\%3A_Millions_Without_Power_In_Sao_Pau lo_And_Rio_De_Janeiro_After_Electrical_Outage> 
M. Dummet, “Bangladesh Suit Ban to Save Power,” BBC News, September 2 (2009) $<$ http://news.bbc.co.uk/2/hi/south_asia/8234144.stm>

EATON, Blackout Tracker: United States Annual Report 2012, <www.eaton.com/blackouttracker> Accessed February 14, 2014.

Economic and Social Research Council, Conference on Urban Vulnerability and Network Failure, Centre for Sustainable Urban Regional Futures, University of Salford, United Kingdom, April 29-30, 2004.

P.N. Edwards, "Infrastructure and Modernity: Force, Time, and Social organization in the History of Sociotechnical Systems,” in T.J. Misa, P. Brey, and A. Feenberg, eds, Modernity and Technology (Cambridge, MA: The MIT Press, 2003).

Energy News, "The Exceptional Heatwave in Argentina Leads to Cuts for Several days in Electricity Supply,” January 9 (2014) http://www.energynews.es/english/the-exceptional-heat-wave-inargentina-leads-to-cuts-for-several-days-in-electricity-supply/ Accessed February 24, 2014.

T. Espiner, “CIA: Cyberattack Caused Multiple-City Blackout,” CNET News, January 22 (2008) <http://news.cnet.com/2100-7349_3-6227090.html> Accessed February 24, 2014.

G. Gatehouse, “Baghdad Diary: Searching for Power,” BBC News, June 29 (2010) $<$ http://www.bbc.co.uk/news/10437279>

R. Gilbert and A. Perl, Transport Revolutions: Moving People and Freight without Oil (London: Earthscan, 2008).

J. Glanz, "The Nation: A Nation Unplugged; Its Coils Tighten, and the Grid Bites Back”, New York Times, August 17 (2003) < http://www.nytimes.com/2003/08/17/weekinreview/the-nation-anation-unplugged-its-coils-tighten-and-the-grid-bites-back.html?pagewanted=all\&src=pm> Accessed February 24, 2014.

S. Graham, "When Infrastructures Fail," in S. Graham, ed., Disrupted Cities: When Infrastructure Fails (New York/London: Routledge, 2010).

The Guardian "Hugo Chávez Extends Easter Holiday to Save Electricity,” March 25 (2010) <http://www.guardian.co.uk/world/2010/mar/25/hugo-chavez-venezuela-easter-holidays>

R. Harrabin, “Britain 'Could Face Blackouts by 2016',” BBC News, September 11 (2009) $<$ http://news.bbc.co.uk/2/hi/science/nature/8249540.stm>

C. Haviland, “Nepal Becomes Land of the Blackout,” BBC News, January 28 (2009) $<$ http://news.bbc.co.uk/2/hi/south_asia/7854167.stm>

International Energy Agency (2010) World Energy Outlook 2010 (Paris: OECD/IEA).

International Energy Agency (2005) Learning from the Blackouts: Transmission System Security in Competitive Electricity Markets (Paris: OECD/IEA Publications).

N. Iqbal, “Pakistan's Heatwave and a Deadly Lack of Energy Policy,” The Guardian, June 7 (2010) <http://www.guardian.co.uk/commentisfree/2010/jun/07/pakistan-energy-policy-provingdeadly>

M. Isaac and D. van Vuuren, "Modelling Global Residential Energy Sector Demand for Heating and Air Conditioning in the Context of Climate Change,” Energy Policy 37 (2009) 507-21.

W. Kröger, Managing and Reducing Social Vulnerabilities from Coupled Critical Infrastructures (Geneva: International Risk Governance Council, 2007).

W. Kröger, ,Der Umgang mit systemischen Risiken - Das Angebot des International Risk Governance Council', Präsentation in der Vortragsreihe „Umgang mit gesellschaftrelevanten Risiken“, ETH Zürich, April 13 (2005) <http://www.lsa.ethz.ch/news/050413-VortragsreiheETH-Handout.pdf> Accessed May 20, 2011.

E.J. Lerner, “What's Wrong with the Electric Grid?” The Industrial Physicist (October/November, 2003) 8-13.

R.G. Little, "Managing the Risk of Cascading Failure in Complex Urban Infrastructures," in S. Graham, ed., Disrupted Cities: When Infrastructure Fails (New York/London: Routledge, 2010).

T.M. Luke, "Power Loss or Blackouts: The Electricity Network Collapse of August 2003 in North America,” in S. Graham, ed., Disrupted Cities: When Infrastructure Fails (New York/London: Routledge, 2010).

C. McGreal, "Power Cuts a Good Sign, Sceptical South Africans Told,” The Guardian, January 21 (2008a) <http://www.guardian.co.uk/world/2008/jan/21/southafrica.chrismcgreal> 
C. McGreal, "Mines Shut as South Africa Faces Electricity 'Emergency',” The Guardian, January 25 (2008b) <http://www.guardian.co.uk/world/2008/jan/25/southafrica.business>

S. Mehrota, "Energy and Peace: The Dangers of Our Slow Energy Transition,” Open Democracy, July 13 (2011) <http://www.opendemocracy.net/shruti-mehrota-benedick-bowie/energy-andpeace-dangers-of-our-slow-energy-transition>

National Research Council, Committee on the Societal and Economic Impacts of Severe Space Weather Events (Washington, DC: National Academies Press, 2008)

National Science and Technology Council, A Policy Framework for the $21^{\text {st }}$ Century Grid: Enabling Our Secure Energy Future (Washington DC: Executive Office of the President of the United States, 2011).

D. Nye, When the Lights Went Out: A History of Blackouts in America (Cambridge, MA: MIT Press, 2010).

C. Perrow, Normal Accidents: Living with High-Risk Technologies (New York: Basic Books, 1984).

C. Perrow, The Next Catastrophe: Reducing our Vulnerabilities to Natural, Industrial and Terrorist Disaster (Princeton: Princeton University Press, 2007).

Planet Green "My Conversation with Stan Cox,” June 30 (2010) $<$ http://planetgreen.discovery.com/tech-transport/author-stan-cox-uncomfortable-truth-airconditioning-interview.html>

$P R$ Web "Global Sales of Air Conditioning Systems to Reach 85 Million Units in 2012, According to New Report by Global Industry Analysts,” November 13 (2008)

$<$ http://www.prweb.com/releases/air_conditioning_systems/room_packaged/prweb1606604.h tm>

G. Prins, “On Condis and Coolth,” Energy and Buildings 18 (1992) 251-8.

B. Shankar, "Global Demand for Electric Cars Could Surpass Supply Soon,” International Business Times, June 17 (2010) <http://www.ibtimes.com/articles/29170/20100617/electric-carsgeneral-motors-byd-auto-toyota-alternative-technologies-charging-stations-plug-in-hybr.htm>

S. Teske, Energy [R] evolution: A Sustainable World Energy Outlook (Greenpeace International/European Renewable Energy Council, 2010).

Union for the Coordination of the Transmission of Electricity, Final Report of the Investigation Committee on the 28 September 2003 Blackout in Italy (2004) $<$ http://www.rae.gr/old/cases/C13/italy/UCTE_rept.pdf >

J. Vidal, “Australians Fight Fear of Power Crisis with Giant Solar Site,” The Guardian, October 26 (2006) <http://www.guardian.co.uk/environment/2006/oct/26/energy.australia>

J. Watts, "June-December: China Resorts to Blackouts to Meet Energy Saving Targets," The Guardian, February 3 (2011)

$<$ http://www.guardian.co.uk/environment/gallery/2011/feb/03/china-year-inenvironment?picture $=371022395 \# /$ ?picture $=371370996 \&$ \&index $=14>$

J. Watts, “China Resorts to Blackouts in Pursuit of Energy Efficiency,” The Guardian, September 19 (2010) <http://www.guardian.co.uk/world/2010/sep/19/china-blackouts-energy-efficiency>

World Bank The China New Energy Vehicles Program: Challenges and Opportunities (2011) $<$ http://siteresources.worldbank.org/EXTNEWSCHINESE/Resources/31965371202098669693/EV_Report_en.pdf> Accessed May 14, 2011.

World Bank Lights Out? The Outlook for Energy in Eastern Europe and Central Asia (Washington, DC., 2010).

B. Wynne, "Unruly Technology: Practical Rules, Impractical Discourses and Public Understanding," Social Studies of Science 18:1 (1988) 147-67.

C. Yuill "Emotions After Dark - A Sociological Impression of the 2003 New York Blackout," Sociological Research Online 9:3 (2004) <http://www.socresonline.org.uk/9/3/yuill.html> Accessed February 23, 2014. 